\title{
Nursing Arts
}

Vol 12, No 2 Desember 2018,

ISSN: 1978-6298 (Print)

\section{FAKTOR YANG BERHUBUNGAN DENGAN KEPUTIHAN PADA REMAJA PUTRI The Related Factors To Leucorrhoea In Teenage Girls Students Sri Juliani ${ }^{1 *}$ \\ ${ }^{1}$ Dosen D4 Kebidanan, Fakultas Farmasi Dan Kesehatan, Institut Kesehatan Helvetia, Medan, Indonesia \\ *Email: srijuliani@helvetia.ac.id}

\author{
Artikel history \\ Dikirim, Agustus $4^{\text {th }}, 2018$ \\ Ditinjau, September $19^{\text {th }}, 2018$ \\ Diterima, Desember $13^{\text {th }}, 2018$
}

\begin{abstract}
Background: Leucorrhoea is a female reproductive health problem. More than $50 \%$ of women around the world have experienced it. Leucorrhoea does not actually need to be treated, but most women do not know about vaginal discharge and its causes so that if not treated properly will cause infertility and are the initial symptoms of uterine cancer. Objective: this study was to determine the factors associated with the vaginal discharge in Taman Siswa Senior High School. Method : This research was conducted was analytic survey research with a cross sectional approach. The population of this study were all teenage girls in Taman Siswa Senior High School as many as 207 girls from 8 sampling classes with Proportional Stratifies Random Sampling so that a sample of 136 people was obtained. Data analysis in this study is analysis univariate, bivariate and multivariate Results : of the chi-square test with the value (sig $\alpha<.05)$ which means that there is a significant relationship between knowledge about vulva hygiene $(p=.006)$, attitudes about vulva hygiene $(p=.004)$, use of pantyliners $(p=.004)$, and use of vaginal cleaning fluid $(p=.025)$. The results of the research test with the Enter method with the value (sig $\alpha<.05)$ which means that it greatly affects the occurrence of vaginal discharge, attitudes (sig =.008) and the use of pantyliner (sig =.001). Conlousion: From the results of this study it can be concluded that the factors associated with the incidence of vaginal discharge in adolescent girls in Taman Siswa Senior High School Binjai are knowledge, attitude, pantyliner usage, frequency of pantyliner replacement, and use of vaginal cleaning fluid, as well as pantyliner use variables that influence adolescents to the incidence of vaginal discharge in Taman Siswa senior high school Binjai in 2018.
\end{abstract}

Keywords: Factors, Leucorrhoea, and Adolescents

\begin{abstract}
ABSTRAK
Pendahuluan : Keputihan merupakan salah satu masalah kesehatan reproduksi wanita. Lebih dari 50\% perempuan diseluruh dunia pernah mengalaminya. Keputihan sebenarnya tidak perlu diobati, namun kebanyakan wanita tidak mengetahui tentang keputihan dan penyebabnya sehingga jika tidak ditangani dengan baik akan menibulkan kemandulan dan merupakan gejala awal dari kanker rahim. Tujuan : penelitian ini adalah untuk mengetahui faktor yang berhubungan dengan Keputihan di SMA Taman Siswa Binjai. Metode :Penelitian ini dilakukan menggunakan jenis penelitian survei analitik dengan pendekatan cross sectional. Populasi penelitian ini adalah seluruh remaja putri di SMA Taman Siswa Binjai sebanyak 207 remaja putri dari 8 kelas pengambilan sampel dengan Proportional Stratifies Random Sampling sehingga didapatkan besar sampel sebanyak 136 orang.Analisa data dalam penelitian ini adalah analisa univariat, bivariat dan multivariat. Hasil : penelitian dari ujichi-square dengan nilai (sig $\alpha$ $<0,05)$ yang berartiterdapat hubungan yang signifikan antara pengetahuan tentang vulva hygiene $(p=0,006)$, sikap tentang vulva hygiene $(p=0,004)$, pemakaian pantyliner $(p=0,004)$, dan pemakaian cairan pembersih vagina $(p=0,025)$. Hasil uji penelitian dengan metode Enter dengan nilai (sig $\alpha<0,05)$ yang berarti sangat memengaruhi terjadinya Keputihan, sikap $($ sig $=0,008)$ dan pemakaian pantyliner $($ sig=0,001).Kesimpulan : penelitian ini dapat disimpulkan bahwa faktor yang berhubungan dengan Keputihan pada remaja putri di SMA Taman Siswa Binjai adalah pengetahuan, sikap, pemakaian pantyliner, frekuensi penggantian pantyliner, dan pemakaian cairan pembersih vagina, serta variabel pemakaian pantyliner yang memengaruhi remaja terhadap Keputihan di SMA Taman Siswa Binjai Tahun 2018.
\end{abstract}

Kata Kunci : Faktor, Keputihan, dan Remaja 


\section{PENDAHULUAN}

Kesehatan reproduksi diartikan sebagai suatu kondisi sehat secara menyeluruh baik kesejahteraan fisik, sosial dan mental yang utuh dalam segala hal yang bekaitan dengan fungsi, peran dan proes reproduksi yang dimiliki oleh remaja.Kesehatan reproduksi pada wanita tidak terlepas pada kesehatan organ intim.Tentu kita perlu sadari bahwa menjaga kesehatan reproduksi sangat penting.Salah satu hal yang dapat kita lakukan adalah menjaga kebersihan atau higienitas, terutama pada daerah sekitar vagina.

Keputihan merupakan salah satu gangguan klinis yang sering dikeluhkan oleh semua wanita. Remaja putri yang baru memasuki masa pubertas dengan segala bentuk fenomena perubahan pada diri mereka, masalah ini dapat berdampak negatif jika tidak ditangani sejak dini.(1) Keputihan atau flour albus adalah kondisi vagina saat mengeluarkan cairan atau lendir yang menyerupai nanah.(2) Keputihan merupakan permasalahan klasik pada kebanyakan kaum wanita. Ironisnya kebanyakan wanita tidak mengetahui tentang keputihan dan penyebab keputihan. Jika tidak ditangani dengan baik, keputihan bias berakibat fatal, kemandulan dan kehamilan ektopik (hamil diluar kandungan) bias menjadi salah satu akibat keputihan. Gejala awal kanker Rahim biasanya dimulai dengan keputihan.(3) Keputihan tidak selamanya merupakan penyakit karena ada juga keputihan yang normal. Oleh sebab itu, keputihan dibagi menjadi dua, yaitu keputihan fisiologis dan patologis.Keputihan yang fisiologis terjadi pada kaum wanita yang pertama kali haid, yang biasanya terjadi di akhir siklus haid. Keputihan jenis ini akan sembuh sendiri, dan tidak berbau dan berwarna putih jernih. Keputihan yang patologis adanya infeksi bakteri, jamur, virus, kemudian terjadi reaksi akibat penggunaan bahan kimia seperti memakai cuci vagina atau menggunakan pembalut yang terlalu lama dan keputihan cenderung berbau busuk, berwarna kehijauan dan kadang-kadang disertai rasa gatal.(4)

\section{Berdasarkan data World Health} Organization 2010 (WHO) masalah kesehatan reproduksi perempuan yang buruk telah mencapai $33 \%$ dari jumlah total beban penyakit yang diderita para perempuan di dunia salah satunya adalah keputihan.(5) Jumlah wanita di dunia yang pernah mengalami keputihan $75 \%$, sedangkan wanita Eropa yang mengalami keputihan sebesar 25\%. Angka ini lebih besar dibandingkan dengan masalah reproduksi pada kaum lakilaki yang hanya mencapai $12,3 \%$ pada usia yang sama dengan kaum wanita. Data tersebut menunjukkan bahwa keputihan pada wanita di dunia, Eropa, dan di Indonesia cukup tinggi.(6)

Menurut data Survei Demografi dan Kesehatan Indonesia (SDKI) 2012 menunjukkan bahwa sekitar $18 \%$ wanita umur 15-49 tahun pernah mengalami keputihan, prevalensi keputihan tertinggi terjadi pada wanita belum menikah sebanyak $21 \%$, dan keputihan terjadi pada wanita tidak tamat SMA sebanyak $11 \%$.(7) Menurut data penelitian tentang reproduksi menyatakan bahwa $75 \%$ wanita didunia pernah mengalami keputihan paling tidak sekali dalam hidup dan $45 \%$ diantaranya mengalami keputihan 2 kali dalam hidup.(8)

Menurut data Profil Kesehatan Provinsi Sumatera Utara Tahun 2012, remaja putri umur 15-19 tahun sebanyak 648.829 jiwa, sebanyak 1.566 kasus Infeksi Menular seksual (IMS) yang terjadi dan didalam nya terdapat akibat infeksi yang berawal dari keputihan.(9)

Banyaknya wanita yang mengalami keputihan ini disebabkan karena beberapa hal salah satunya adalah kurangnya menjaga kebersihan organ reproduksi, dengan itu organ reproduksi dapat dijaga dengan sering mengganti pakaian dalam, paling tidak sehari dua kali setelah mandi, perlu diperhatikan agar tidak terjadi kelembapan pada organ kewanitaan maka harus sering mengganti celana dalam. Selain itu, hindari menggunakan pakaian dalam yang terlalu ketat karena selain gerah, juga menyebabkan peredaran darah tidak lancar.(6) 
Masa remaja adalah masa yang khusus dan penting karena merupakan masa transisi yang ditandai dengan perubahan fisik, emosi dan psikis.(10) Pada masa remaja, perubahan organ biologi terjadi cepat namun tidak seimbang dengan perubahan mental emosional. Secara etimiologi, remaja berarti "tumbuh menjadi dewasa". Definisi remaja (adolescence) menurut World Health Organization (WHO) adalah periode usia antara 10 sampai 19 tahun, sedangkan Perserikatan Bangsa-Bangsa (PBB) menyebut kaum muda (youth) untuk usia anatara 15 sampai 24 tahun. (11)

Masalah reproduksi pada remaja perlu mendapat penanganan serius, karena masalah tersebut banyak muncul di Indonesia salah satunya disebabkan karena faktor pengetahuan dan perilaku yang kurang baik dalam mencegah maupun menangani keputihan.(12)

Banyak wanita di Indonesia yang tidak tahu tentang keputihan sehingga mereka menganggap keputihan adalah sebagai hal yang sudah biasa dan tidak perlu dikhawatirkan, di samping itu rasa malu ketika para wanita/remaja mengalami keputihan yang membuat wanita/remaja tersebut tidak berkonsultasi ke dokter. Keputihan tidak bisa dianggap hal yang biasa, karena akibat dari penanganan keputihan yang tidak cepat ditangani tidak hanya bisa mengakibatkan kemandulan atau hamil di luar kandungan, keputihan juga bisa merupakan awal dari kanker leher rahim (kanker serviks) yang bisa berujung pada kematian kalau tidak dikonsultasikan pada petugas kesehatan sejak dini.(13)

Hal ini terbukti dari penelitian yang dilakukan oleh Popy Wulandari, pada tahun 2016 tentang hubungan perilaku vulva hygiene dengan Keputihan patologi pada siswa kelas X di SMA Muhammadiyah 7 Yogyakarta bahwa ada hubungan perilaku vulva hygiene dengan Keputihan, dari 36 responden sebagian besar adalah responden yang perilaku vulva hygiene dengan kategori kurang yaitu sebanyak 51,4\%. Penyebabnya adalah kurangnya menjaga kebersihan atau perilaku vulva hygiene yang tidak baik.(8)
Menurut Anisa Persia, Rina Gustia, dan Elizabeth Bahar didalam penelitiannya yang berjudul hubungan pemakaian panty liner dengan kejadian flour albus pada siswi SMA di kota Padang berdasarkan wawancara terpimpin (kuesioner) bahwa flour albus lebih banyak terjadi pada responden yang memakai panty liner $(69,2 \%)$, jika dibandingkan dengan responden yang tidak memakai panty liner $(28,7 \%) .(14) B e r d a s a r k a n$ penelitian yang berjudul Faktor yang Berhubungan Dengan Keputihan Patologis Siswi SMAN 1 Simpang Hilir oleh Abrori, Andri Dwi Hernawan, dan Ermuyadi tahun 2017. Penelitian tersebut merupakan penelitian observasional analitik dengan pendekatan cross sectional, didapati hasil dari 59 responden ada 30 responden memiliki pengetahuan kurang baik tentang vulva hygiene, sebanyak 21 responden $(72,4 \%)$ menggunakan pembersih vagina, $1 \%$ mengalami kegemukan badan, 31 responden $(64,6 \%)$ menggunakan celana dalam ketat, dan 27 responden $(67,5 \%)$ menggunakan toilet umum.(15)

Berdasarkan uraian di atas dan survei awal yang telah dilakukan di SMA Taman Siswa Binjai pada bulan Juli 2018, diketahui bahwa dari 10 remaja putri terdapat 7 remaja yang mengalami keputihan, tidak mengerti cara melakukan vulva hygiene dengan benar, memakai pantyliner serta membersihkan vagina selalu dengan cairan pembersih vagina dan tisu dan terdapat 3 remaja putri yang selalu menjaga kebersihan organ kewanitaannya dengan cara mengganti pakaian dalamnya apabila lembab, tidak pernah memakai pantyliner dan cairan pembersih vagina juga selalu mengeringkan vaginanya apabila selesai BAK/BAB. Berdasarkan uraian di atas maka peneliti tertarik untuk melakukan penelitian mengenai faktor yang berhubungan dengan Keputihan pada remaja putri di SMA Taman Siswa Binjai Tahun 2018.

Tujuan penelitian ini untuk mengetahui hubungan pengetahuan tentang, sikap, pemakaian pantyliner, pemakaian cairan pembersih vagina dan faktor yang 
mempengaruhi dengan Keputihan pada remaja putri di SMA Taman Siswa Binjai tahun 2018.

\section{METODE PENELITIAN}

Penelitian ini dilakukan tahun 2018 dengan sampel dalam penelitian yaitu remaja putri di SMA Taman Siswa Binjai Tahun 2018, dengan menggunakan teknik pengambilan sampel random sampling sebanyak 136 orang.Jenis penelitian yang digunakan adalah survey analitik dengan pendekatan hubungan antara variable dependen dengan varable independen. Sumber data bersumber dari hasil wawancara terhadap remaja putri dengan menggunakan kuesioner. Analisis data menggunakan program SPSS, analisis univariat digunakan untuk mendeskripsikan distribusi dan frekuensi variable, analisis bivariat untuk melihat hubungan variable dependen dengan variable independent dengan uji Chi- Square, hasil kemudian dilanjutkan dengan analisis multivariate dengan model Logistic regression.(16)

\section{HASIL}

Analisis Univariat : Tabel 1 bmenunjukkan tentang distribusi frekuensi pengetahuan remaja putri mayoritas berada pada kategori cukup yaitu sebanyak 70 remaja $(51,5 \%)$, dan minoritas berada pada kategori baik yaitu sebanyak 32 remaja $(23,5 \%)$, distribusi frekuensi sikap remaja putri mayoritas berada pada kategori negatif yaitu sebanyak 85 remaja $(62,5 \%)$, dan kategori positif yaitu sebanyak 51 remaja $(37,5 \%)$, distribusi frekuensi pemakaian pantyliner terlihat 42 remaja $(31,0 \%)$ memakai pantyliner, sedangkan 94 remaja $(69,0 \%)$ tidak memakai pantyliner. distribusi frekuensi penggantian pantyliner dari 42 remaja putri yang menggunakan pantyliner menunjukkan bahwa 28 remaja (56\%) mengganti pantyliner kurang dari 2 kali per hari, dan 14 remaja (28\%) mengganti pantyliner lebih dari 2 kali per hari, distribusi frekuensi pemakaian cairan pembersih vagina menunjukkan bahwa 62 remaja $(45,6 \%)$ memakai cairan pembersih vagina, sedangkan 74 remaja $(54,4 \%)$ tidak memakai cairan pembersih vagina, distribusi frekuensi Keputihan menunjukkan bahwa sebanyak 86 remaja $(63,2 \%)$ mengalami keputihan normal, sedangkan 50 remaja $(36,8 \%)$ mengalami keputihan abnormal. 
Tabel 1. Distribusi Frekuensi Pengetahuan, Sikap, Pemakaian Pantyliner dan pemakaian Pembersih Vagina Pada Remaja Putri di SMA Taman Siswa Binjai Tahun 2018

\begin{tabular}{ccc}
\hline Variabel & \multicolumn{2}{c}{ Jumlah } \\
\cline { 2 - 3 } & F & \% \\
\hline Pengetahuan Remaja Putri & 32 & 23,5 \\
Baik & 70 & 51,5 \\
Cukup & 34 & 25,0 \\
Kurang & & \\
Sikap Remaja Putri & 51 & 62,5 \\
Positif & 85 & \\
Negatif & & 31,0 \\
Pemakaian Pantyliner & 42 & 69,0 \\
Pakai & 94 & 56,0 \\
Tidak pakai & & 28,0 \\
\hline 2 kali & 28 & \\
$\geq 2$ kali & 14 & 45,6 \\
Pakai & & 54,4 \\
\hline Tidak pakai & 62 & \\
Keputihan & 74 & 63,2 \\
Normal & & 36,8 \\
Abnormal & 86 & \\
\hline
\end{tabular}

Analisis Bivariat :Berdasarkan tabel 2. Pengetahuan dengan Keputihan memiliki hubungan yang signifikan. Pengetahuan dengan Keputihan normal, baik 11,7, cukup 31,6 dan kurang 20,0 dibandingkan dengan pengetahuan dengan Keputihan abnormal, baik 13,2, cukup 19,8 dan kurang 3,6. Uji chi-square diperolah nilai $\mathrm{p}=0,006$. Ada hubungan yang signifikan antara sikap dengan Keputihan. Sikap dengan Keputihan normal, positif 17,9 dan negatif 45,1 dan sikap dengan Keputihan abnormal, positif 20,0 dan negatif 17,0 . Uji chi-squarediperoleh nilai $\mathrm{p}=$ 0,004 . Ada hubungan yang signifikan antara pemakaian pantyliner dengan Keputihan.
Pemakaian pantyliner dengan keputihan normal 26,7 dan keputihan abnormal 4,2, uji chi-square diperoleh nilai $\mathrm{p}=0,001$. Pada frekuansi penggantin pantyliner $<2$ kali perhari keputihan normal 64,3, keputihan abnormal 2,3, frekuensi pengantian pantyliner $\geq 2$ kali perhari keputihan normal 21,5 dan keputihan abnormal 11,9 dengan hasil uji chi-square diperoleh nilai $\mathrm{p}=0,011$. Ada hubungan yang signifikn antara pemakaian cairan pembersih vagina dengan Keputihan. Pada yang memakai cairan pembersih vagina dan mengalami keputihan normal 33,8 dan yang keputihan abnormal 11,7. Uji chi-square diperoleh nilai $\mathrm{p}$ $=0,025$.

Tabel 2. Tabulasi Silang Pengetahuan, Sikap, Pemakaian panyliner, Frekuensi Penggantian Pantyliner dan Pemakaian Cairan Pembersih Vagina dengan Keputihan Pada Remaja

Putri di SMA Taman Siswa Binjai Tahun 2018

\begin{tabular}{|c|c|c|c|c|c|c|c|}
\hline \multirow{3}{*}{ Faktor } & \multicolumn{4}{|c|}{ Keputihan } & \multirow{2}{*}{\multicolumn{2}{|c|}{ Total }} & \multirow{3}{*}{ P-Value } \\
\hline & \multirow{2}{*}{$\begin{array}{c}\text { Normal } \\
f\end{array}$} & \multicolumn{3}{|c|}{ Abnormal } & & & \\
\hline & & $\%$ & $\mathbf{F}$ & $\%$ & $\mathbf{F}$ & $\%$ & \\
\hline \multicolumn{8}{|c|}{ Pengetahuan } \\
\hline Baik & 16 & 11,7 & 18 & 13,2 & 34 & 25,0 & \\
\hline Cukup & 43 & 31,6 & 27 & 19,8 & 70 & 51,4 & 0,006 \\
\hline Kurang & 27 & 20,0 & 5 & 3,6 & 32 & 23,6 & \\
\hline \multicolumn{8}{|l|}{ Sikap } \\
\hline Positif & 24 & 17,9 & 27 & 20,0 & 51 & 37,5 & 0,004 \\
\hline
\end{tabular}




\begin{tabular}{cccccccc} 
Negatif & 62 & 45,1 & 23 & 17,0 & 85 & 52,5 & \\
\hline $\begin{array}{c}\text { Pemakaian Pantyliner } \\
\text { Pakai }\end{array}$ & 36 & 26,7 & 6 & 4,2 & 42 & 30,8 & 0,001 \\
Tidak pakai & 50 & 36,7 & 44 & 32,4 & 94 & 69,2 & \\
\hline $\begin{array}{c}\text { Frekuensi Penggantian } \\
\text { Pantyliner }\end{array}$ & & & & & & & \\
$<2$ kali & 27 & 64,3 & 1 & 2,3 & 28 & 66,7 & 0,011 \\
$>2$ kali & 9 & 21,5 & 5 & 11,9 & 14 & 33,3 & \\
\hline Pemakaian Cairan & & & & & & & \\
Pembersih Vagina & & & & & & & \\
$\quad$ Pakai & 46 & 33,8 & 16 & 11,7 & 62 & 44,5 & 0,025 \\
Tidak pakai & 40 & 29,4 & 34 & 25,1 & 74 & 55,5 & \\
\hline
\end{tabular}

Analisis Multivariat :Berdasarkan tabel 3. Tahap-1 diketahui bahwa variabel pengetahuan, sikap, pemakaian pantyliner, dan pemakaian cairan pembersih vagina mempunyai nilai Sig < 0,25, dan dapat diikutsertakan dalam tahap-2 untuk mengetahui variabel berpengaruh (dominan).Berdasarkan tahap-2 diketahui bahwa ada 2 variabel penelitian yang signifikan. Variabel signifikan terebut adalah variabel sikap dan pemakaian pantyliner dengan nilai variabel sikap $\mathrm{Sig}=0,008<0,05$ yang berpengaruh dengan pengaruh 2.924 atau 2 kali lipat mempengaruhi remaja terhadap Keputihan, dan variabel pemakaian pantyliner Sig= 0,01 < 0,05 yang berpengaruh dengan pengaruh 5.273 atau 5 kali lipat mempengaruhi remaja terhadap Keputihan.

Tabel .3. Uji Regresi Logistik Tahap-1 dan Tahap-2

\begin{tabular}{llcccccc}
\hline \multicolumn{1}{c}{ Variables in the Equation } & B & S.E. & Wald & df & Sig. & Exp(B) \\
\hline Step 1 $^{\text {a }}$ & Pengetahuan(1) & .773 & .409 & 3.562 & 1 & .059 & 2.165 \\
& Sikap(1) & 1.073 & .406 & 6.982 & 1 & .008 & 2.924 \\
& Pantyliner(1) & 1.663 & .518 & 10.295 & 1 & .001 & 5.273 \\
& Cairan_pembersih_vagina(1) & .541 & .410 & 1.741 & 1 & .187 & 1.718 \\
& Constant & -1.051 & .391 & 7.215 & 1 & .007 & .350 \\
\hline Step 2 & Pengetahuan(1) & .773 & .409 & 3.562 & 1 & .059 & 2.165 \\
& Sikap(1) & 1.073 & .406 & 6.982 & 1 & .008 & 2.924 \\
& Pantyliner(1) & 1.663 & .518 & 10.295 & 1 & .001 & 5.273 \\
& Cairan_pembersih_vagina(1) & .541 & .410 & 1.741 & 1 & .187 & 1.718 \\
& Constant & -1.051 & .391 & 7.215 & 1 & .007 & .350 \\
\hline
\end{tabular}

\section{PEMBAHASAN}

Hubungan Pengetahuan Remaja Putri dengan Keputihan: Berdasarkan hasil analisis bivariat diketahui dari 136 responden yang pengetahuannya baik dan terjadi keputihan normal yaitu sebanyak 16 orang $(11,7 \%)$, keputihan abnormal sebanyak 18 orang $(13,2 \%)$, yang pengetahuannya cukup dan terjadi keputihan normal yaitu sebanyak 43 orang (31,6\%), keputihan abnormal sebanyak 27 orang $(19,8)$ dan responden yang pengetahuannya kurang dan terjadi keputihan nomal yaitu sebanyak 27 orang $(20,0 \%)$, keputihan abnormal sebanyak 5 orang $(3,6 \%)$. Berdasarkan hasil uji statistik chi-square didapatkan nilai $p=0,006$ pada tingkat kepercayaan 95\% $(0,05)$. Dengan demikian, $p$-value $(0,006)<0,05$ yang menunjukkan bahwa ada hubungan yang signifikan antara pengetahuan pada remaja putri dengan Keputihan di SMA Taman Siswa Binjai tahun 2018.

Pengetahuan adalah hasil dari "tahu", dan ini terjadi setelah seseorang melakukan penginderaan terhadap sesuatu obyek tertentu. Penginderaan terjadi melalui panca indera manusia, yakni indera penglihatan, pendengaran, 
penciuman, rasa dan raba.(17) Sebagian besar pengetahuan manusia diperoleh melalui mata dan telinga.Pengetahuan tentang vulva hygiene merupakan suatu hal yang diketahui tentang cara atau tindakan membersihkan kelamin perempuan bagian luar untuk menjaga kesehatan alat kelamin yang dilakukan dalam kehidupan seharihari sehingga terhindar dari gangguan alat reproduksi dan mendapatkan kesejahteraan fisik dan psikis serta meningkatkan derajat kesehatan. Seseorang yang tidak memiliki pemahaman tentang reproduksi akan cenderung mengabaikan kesehatan reproduksi dan pada akhirnya ia akan memiliki tindakan yang membahayakan bagi dirinya sendiri. Salah satunya akibat kurangnya pemahaman vulvahygienesehingga terjadinya gangguan kesehatan reproduksi seperti keputihan.(18)

Penelitian ini sejalan dengan penelitian yang dilakukan Abrori, Andri D.Hernawan dan Ermulyadi tahun 2017 dengan judul "Faktor yang Berhubungan dengan Keputihan Patologis Siswi SMAN 1 Simpang Hilir Kabupaten Kayong Utara". Hasil penelitian pada variabel pengetahuan vulva hygiene menunjukkan nilai sig $p=0,036<0,05$ yang artinya adanya hubungan pengetahuan remaja putri dengan Keputihan.(15)

Penelitian ini tidak sejalan dengan penelitian Pety Merita sari dengan menyatakan bahwa responden yang berpengetahuan baik tentang keputihan akan tetap mengalami keputihan yang diakibatkan perilaku yang kurang baik dalam menjaga kebersihan organ genetalianya.(18)

Penelitian ini juga sejalan dengan penelitian Tiaradevi dimana remaja yang kurang pengetahuan dan informasi tentang kesehatan reproduksi terutama keputihan akan berdampak pula pada perilaku remaja dalam menjaga kebersihan alat genitalianya. Karena pengetahuan dan perilaku perawatan yang baik merupakan faktor penentu dalam memeliharan kebersihan alat geitalia(5).

Menurut asumsi peneliti bahwa mayoritas remaja putri di SMA Taman Siswa yang mengalami keputihan abnormal terdapat pada remaja yang berpengetahuan cukup, dan yang berpengetahuan baik mengalami keputihan abnormal sebanyak 18 orang namun pada yang bepengetahuan kurang hanya 5 orang yang keputihan abnormal. Teori mengatakan semakin baik pengetahuan sesorang maka semakin baik pula kualitas kesehatannya, namun ini tidak berlaku pada Keputihan, karena tidak dapat dipastikan bahwa wanita yang berpengetahuan baik tidak akan mengalami keputihan abnormal, karena keputihan abnormal dapat disebabkan oleh faktor lain seperti kebersihn alat kelamin, penggunaan celana dalam yang ketat atau cara membasuh vagina dengan cara yang salah.

Hubungan Sikap Remaja Putri dengan Keputihan: Berdasarkan hasil analisis bivariat diketahui dari 136 responden yang sikapnya positif dan terjadi keputihan normal yaitu sebanyak 24 orang $(17,9 \%)$ dan keputihan abnormal yaitu sebanyak 27 orang (20,0\%), dari 136 responden yang sikapnya negatif dan terjadi keputihan normal yaitu sebanyak 62 orang $(45,1 \%)$ dan keputihan abnormal yaitu sebanyak 23 orang $(17,0 \%)$. Berdasarkan hasil uji statistik chi-square didapatkan nilai $p=0,004$ pada tingkat kepercayaan $95 \%(0,05)$. Dengan demikian, $p$ value $(0,004)<0,05$ yang menunjukkan bahwa ada hubungan yang signifikan antara sikap tentang vulva hygiene pada remaja putri dengan Keputihan di SMA Taman Siswa Binjai tahun 2018. Sikap merupakan reaksi atau respon yang masih tertutup dari seseorang terhadap suatu stimulus atau objek. Menurut Notoadmodjo menjelaskan bahwa sikap itu mempunyai tiga komponen pokok, yaitu kepercayaan (keyakinan), ide dan konsep terhadap suatu objek, kehidupan emosional atau evaluasi suatu objek kecenderungan untuk bertindak.(19) Sikap tentang vulva hygiene merupakan suatu kesiapan atau kesediaan untuk bertindak dalam menjaga kebersihan alat kelamin perempuan untuk menjaga kesehatan alat kelamin itu sendiri dari keputihan. Adapun cara vulva hygiene dengan baik adalah membersihkan vagina secara hatihati dan perlahan, cara membasuh vagina yang benar dari arah depan ke belakang, hindari penggunaan pengharum dan sabun antiseptik secara terus menerus, karena dapat merusak keseimbangan flora normal dalam vagina, 
gantilah celana dalam 2 sampai 3 kali sehari dan menggunakan celana dalam yang bersih serta terbuat dari bahan katun, mencuci tangan sebelum menyentuh vagina, dan jangan menggunakan handuk milik orang lain untuk membersihkan vagina.(13)

Hal ini bertentangan dengan penelitian Ika Tristanti dengan judul "Hubungan Perilaku Personal Genital Dengan Keputihan Pada Siswi Madrasah Aliyah Muhammadiyah Kudus" dengan hasil perhitungan statistik menggunakan uji fisher didapatkan hasil $p$ value 0,734 dengan derajat kemaknaan 5\%, $0,734>0,05$ sehingga dapat disimpulkan tidak terdapat hubungan antara perilaku personal hygiene dengan Keputihan.(20)

Hasil yang sejalan dengan penelitian ini oleh Pety Merita sari menyatakan sikap itu merupakan kesiapan atau kesediaan untuk bertindak dan bukan merupakan elaksanaan motif tertentu, maka hal ini dapat diketahui bahwa dengan sikap yang baik terhadap keberihan organ vagina maka dapat mengindari terjadinya keputihan(18).

Penelitian ini bertolak belakang dari hasil penelitian yang menyatakan bahwa Keputihan yang dialami tidak disebabkan oleh perilaku personal hygiene yang buruk melainkan oleh sebablain, antara lain kelelahan, stress yang berat ataupun kekurang pahaman tentang tanda dan gejala keputihan dan penyebabnya.(20) Keputihan abnormal dapat terjadi pada siapapun walau memiliki sikap positif karena keputihan dapat disebabkan oleh faktor lain seperti stress, memiliki sistem imun yang lemah, lingkungan yang kotor juga pemakain toilet umum yang sering.

Menurut asumsi peneliti bahwa sikap merupakan hal penting untuk kesehatan, semakin baik sikap yang dimiliki semakin baik pula cara kita menjaga kesehatan tersebut. Kenyataannya mayoritas sikap remaja putri di SMA Taman Siswa Tahun 2018 bersikap negatif namun mayoritas yang mengalami keputihan abnormal terjadi pada remaja yang bersikap positif, hal ini juga membuktikan bahwa keputihan abnormal dapat terjadi pada siapapun walau memiliki sikap positif karena keputihan dapat disebabkan oleh faktor lain seperti stress, memiliki sistem imun yang lemah, lingkungan yang kotor juga pemakain toilet umum yang sering.

Hubungan Pemakaian Pantyliner dengan Keputihan: Berdasarkan hasil analisis bivariat diketahui dari 42responden yang memakai pantyiner dan terjadi keputihan normal yaitu sebanyak 36 orang $(26,7 \%)$ dan keputihan abnormal yaitu sebanyak 6 orang $(4,2 \%)$ dan dari 94 responden yang tidak memakai pantyliner dan terjadi keputihan normal yaitu sebanyak 50 orang $(36,7 \%)$ dan keputihan abnormal sebanyak yaitu 44 orang $(32,4)$.Berdasarkan hasil uji statistik chi-square didapatkan nilai $p=0,001$ pada tingkat kepercayaan $95 \%$ dengan $(0,05)$. Dengan demikian, $p$-value $(0,001)<0,05$ yang menunjukkan bahwa ada hubungan yang signifikan antara pemakaian pantyliner dengan Keputihan di SMA Taman Siswa Binjai tahun 2018.

Pantyliner adalah bahan penyerap yang digunakan untuk kebersihan wanita yang dikenakan di celana dalam wanita.Pemakaian pantyliner merupakan salah satu faktor predisposisi timbulnya keputihan. Dimana pada pemakainya akan meningkatkan suhu $1,5^{\circ}$ $\mathrm{C}$, peningkatan kelembapan, dan peningkatan $\mathrm{pH}$ sebesar 0,6 di area vulva dan perineum. Keadaan ini akan meningkatkan kemungkinan terjadinya pertumbuhan kuman dan jamur pathogen penyebab keputihan. Umumnya wanita menggunakannya ketika mendapatan keputihan atau kelebihan cairan lender dari vagina. Namun banyak wanita salah dalam penggunaan pantyliner. Pantyliner seharusnya digunakan dalam waktu singkat.(14)

Hal ini sejalan berdasarkan hasil penelitian oleh Anisa Persia tahun 2015 dengan judul "Hubungan Pemakaian Pantyliner dengan Kejadian Flour albuspada Siswi SMA di Kota Padang Berdasarkan Wawancara Terpimpin (Kuesioner)". Dimana flour albus terjadi pada responden yang tidak memakai pantyliner yaitu sebanyak $28,7 \%$, dan pada responden yang memakai pantyliner yaitu sebanyak 69,2\%. Dari hasil uji statistik yang diperoleh, nilai $\mathrm{p}=0,000<$ 0,05 dapat disimpulkan bahwa terdapat 
hubungan yang bermakna antara pemakaian pantyliner dengan kejadian flour albus.(14)

Hal ini sejalan dengan penelitian yang dilakukan oleh Farage tahun 1997 mendapatkan bahwa pemakaian pantyliner menurunkan jumlah Latobacillus species di vagina sebagai flora normal, sehingga akan memacu pertumbuhan organisme penyebab flour albus. (21)

Hasil penelitian ini mirip dengan penelitian yang dilakukan oleh Dwi Widya Astuti (2016) menyatakan bahwa keputihan yang terjadi disebabkan juga karena meningkatnya pertumbuhan bakteri di pantyliner, dengan nilai $\mathrm{p}$ $=0,002$. $(22)$

Menurut asumsi peneliti bahwa semakin sering remaja putri menggunakan pantyliner maka dapat dipastikan bahwa remaja tersebut akan mengalami keputihan. Walaupun pada umumnya penggunaan rutin pada pantyliner dapat menyebabkan daerah kewanitaan menjadi lembab, dimana kita ketahui bahwa bakteri akan lebih cepat berkembang ditempat yang lembab. Namun kenyataannya di SMA Taman Siswa mayoritas remaja yang mengalami keputihan abnormal terjadi pada remaja yang tidak memakai pantyliner, hal ini dapat dipastikan bahwa wanita yang tidak memakai pantyliner juga dapat mengalami keputihan abnormal, karena keputihan abnormal dapat disebabkan oleh faktor lain seperti kebersihan alat kelamin, lingkungan yang kotor, juga sering bertukar pakaian dengan orang lain.

\section{Hubungan Frekuensi Penggantian}

Pantyliner dengan Keputihan: dari 42 responden yang memakai pantyliner, mayoritas keputihan normal terjadi pada responden yang mengganti pantyliner nya kurang dari 2 kali per hari yaitu sebanyak 27 orang $(64,4 \%)$, sedangkan pada responden yang mengganti pantyliner nya lebih dari 2 kali per hari dan mengalami keputihan normal yaitu sebanyak 9 orang (21,5\%), didapati hasil uji statistik chi-square nilai $p$-value $=0,011$ pada tingkat kepercayaan 95\% dengan $(0,05)$. Dengan demikian, $p$-value $(0,011)<0,05$ yang menunjukkan bahwa ada hubungan yang signifikan antara frekuensi penggantian pantyliner dengan Keputihan pada remaja putri di SMA Taman Siswa Binjai tahun 2018.

Frekuensi secara umum adalah banyaknya sesuatu yang terjadi setiap detiknya. Frekuensi mengganti pantyliner secara teratur dapat mencegah bakteri patogen yang memicu timbulnya penyakit. Menurut pendapat ahli bahwa frekuensi penggantian pantyliner sangat dianjurkan bagi seorang wanita untuk mengganti pantyliner secara teratur $4-5$ kalisehari atau setelah buang air kecil atau mandi untuk menghindari tumbuhnya jamur atau bakteri.(14)

Penelitian ini sejalan dengan penelitian sebelumnya mengenai frekuensi pengganti pantyliner oleh Anisa Persia yang berjudul "Hubungan Pemakaian Panty Liner dengan Kejadian Flour Albus pada Siswi SMA di Kota Padang Berdasarkan Wawancara Terpimpin dengan hasil uji statistik nilai p-value $=0,000$ $<0,05$ disimpulkan bahwa terdapat hubungan yang bermakna antara frekuensi penggantian pantyliner dengan kejadian flour abus.(14)

Wanita yang tidak memakai pantyliner juga dapat mengalami keputihan abnormal, karena keputihan abnormal dapat disebabkan oleh faktor lain seperti kebersihan alat kelamin, lingkungan yang kotor, juga sering bertukar pakaian dengan orang lain. Pada frekuensi penggantian pantyliner didapatkan remaja yang mayoritas keputihan abnormal terjadi pada frekuensi penggantian sebanyak lebih dari 2 kali per hari, namun ada pendapat lain mengatakan semakin sering mengganti pantyliner maka semakin kecil pula peluang terjadinya keputihan,(14) dengan ini dapat dipastikan bahwa keputihan abnormal juga besar kemungkinan dapat terjadi pada frekuensi penggantian pantyliner yang lebih sering, krena keputihan dapat disebabkan oleh faktor lain seperti memakai air yang kotor, penggunaan toilet umum, memakai celana yang terlalu ketat dan pemilihan pantyliner yang salah seperti pantyliner yang banyak mengandung zat kimianya.

Hubungan Pemakaian Cairan Pembersih dengan Keputihan: Berdasarkan hasil analisis bivariat dari 62 responden yang memakai cairan pembersih vagina dan terjadi 
keputihan normal yaitu sebanyak 46 orang $(33,8 \%)$ dan keputihan abnormal yaitu sebanyak 16 orang $(11,7 \%)$, dari 74 responden $(55,5 \%)$ tidak memakai cairan pembersih vagina dan terjadi keputihan normal yaitu sebanyak 40 orang $(29,4 \%)$ dan keputihan abnormal yaitu sebanyak 34 orang $(25,1 \%)$.Berdasarkan hasil uji statistik chisquaredidapatkan nilai $p=0,0019$ pada tingkat kepercayaan 95\% (0,05). Dengan demikian, $p$ value $(0,019)<0,05$ yang menunjukkan bahwa ada hubungan yang signifikan antara pemakaian cairan pembersih vagina pada remaja putri dengan Keputihan di SMA Taman Siswa Binjai tahun 2018.

Cairan pembersih vagina pada umumnya mengandung banyak senyawa kimia seperti kandungan petroleum, syntetic cheminal, dan petrochemil yang dapat merusak kulit dan lingkungan. Penggunaan antiseptik yang banyak dijual dipasaran justru akan mengganggu ekosistem di dalam vagina, terutama $\mathrm{pH}$ dan kehiduoan bakteri baik. Jika pH terganggu maka bakteri jahat akan mudah berkembang lebih banyak dan vagina akan mudah terkena penyakit yang salah satunya ditandai dengan keputihan.(23)

Hal ini sejalan dengan penelitian yang dilakukan oleh Risna Triyani dengan judul "Hubungan Pemakaian Pembersih vagina dengan Keputihan Pada Remaja Putri" didapati hasil uji statistik chi-square dengan hasil taraf signifikansi $\quad 0,000<0,05$ maka terdapat hubungan yang bermakna antara pemakaian pembersih vagina dengan Keputihan.(23)

Menurut asumsi peneliti bahwa pembersih vagina bukan hal yang tidak lazim lagi di kalangan wanita, karena menganggap pembersih vagina adalah salah satu kebutuhan dalam kecantikan. Pada kenyataannya penggunaan cairan pembersih vagina dapat menyebabkan keputihan jika digunakan secara terus menerus. Karena pemakaian pembersih vagina dapat menyebabkan $\mathrm{pH}$ vagina terganggu namun hal ini tidak dapat dipastikan bahwa wanita yang tidak memakai cairan pembersih vagina tidak mengalami keputihan abnormal, karena keputihan abnormal dapat disebabkan oleh faktor lain seperti pemilihan cairan pembersih yang banyak mengandung zat kimia seperti mengandung parfume, kebersihan alat kelamin, penggunaan celana dalam yang ketat, meminjam pakaian orang lain, mambasuh vagina dengan cara yang salah dan lingkungan yang kotor. Hal ini dikarenakan perkembangan bakteri yang merugikan vagina.

\section{Hubungan Faktor Yang Sangat Mempengaruhi Remaja Putri Dengan} Keputihan: Pada uji tahap-2 diketahui bahwa ada 2 variabel penelitian yang signifikan. Variabel signifikan tersebut adalah variabel sikap diperoleh nilai $\mathrm{Sig}=0,008<0,05$ dan varibel pemakaian pantyliner diperoleh nilai $\mathrm{Sig}=0,002(\mathrm{p}<0,05)$ artinya kedua variabel tersebut berpengaruh terhadap Keputihan.

Sikap sangat berpengaruh terhadap kesehatan, semakin baik sikap yang dimiliki semakin baik pula kesehatan yang dimiliki, buruk sikap yang dimiliki semakin buruk pula kualitas kesehatan yang kita miliki.Pantyliner sangat banyak dipasarkan dengan bebas, dengan iklan-iklan menarik yang membuat remaja menjadi tertarik untuk menggunakannya tanpa mencari tau lebih tentang penggunaan maupun kerugiannya.Pantyliner terbuat dari bahan kertas bekas yang diurai lagi dengan zat kimia bernama dioxin, ini merupakan zat pemutih yang dapat berbahaya untuk kulit kelamin. Pantyliner juga yang menyebabkan suhu kelamin menjadi lembab dan membuat bakteri semakin berkembang biak dikelamin, hal ini yang menyebabkan keputihan semakin parah.Pantyliner terbuat dari bahan kertas bekas yang diurai lagi dengan zat kimia bernama dioxin, ini merupakan zat pemutih yang dapat berbahaya untuk kulit kelamin. Pantyliner juga yang menyebabkan suhu kelamin menjadi lembab dan membuat bakteri semakin berkembang biak dikelamin, hal ini yang menyebabkan keputihan semakin parah.

Hasil penelitian ini sejalan dengan penelitian Anisa Persia di SMA Kota Padang, diperoleh $\mathrm{p}=0,000<0,05$, sehingga dapat disimpulkan bahwa ada hubungan penggunaan pantyliner dengan Keputihan.(14) 
Hasil penelitian ini mirip dengan penelitian yang dilakukan oleh Dwi WidyaAstuti (2016) menyatakan bahwa keputihan yang terjadi disebabkan juga karena meningkatnya pertumbuhan bakteri di pantyliner, dengan nilai $\mathrm{p}$ $=0,002$. $(22)$

Menurut asumsi peneliti bahwa sikap dan pemakaian pantyliner merupakan faktor yang berpengaruh dengan Keputihan karena sikap yang buruk seperti tidak menjaga kebersihan kelamin, cara membasuh vagina yang salah, pemakaian pakaian dalam yang ketat akan menimbulkan keputihan dan pemakaian pantyliner yang membuat kelamin selalu lembab membuat kuman semakin banyak bersarang hingga menimbulkan keputihan yang abnormal.

\section{KESIMPULAN}

Terdapat hubungan yang signifikan antara pengetahuan, sikap, pemakaian pantyliner, pemakaian cairan pembersih vagina dengan Keputihan, dan faktor yang sangat mempengaruhi dengan Keputihan adalah sikap dan pemakaian pantyliner.

\section{SARAN}

Diharapkan kepada pihak sekolah untuk dapat memberikan materi edukasi tentang kesehatan reproduksi agar menambah wawasan siswa seputar kesehatan bagian reproduksi.

\section{UCAPAN TERIMA KASIH}

Terima kasih peneliti ucapkan kepada Bapak Julheri, ST, selaku kepala sekolah di SMA Taman Siswa Binjai yang telah memberikan izin kepada peneliti untuk melakukan penelitian dan telah menerima peneliti dengan baik selama dalam melakukan penelitian.

\section{DAFTAR PUSTAKA}

1. Tulus Cwk, Kundre Rm, Bataha Yb. Hubungan Pengetahuan Dan Perilaku Dengan Terjadinya Keputihan Pada Remaja Putri Kelas Xi Di Sma Kristen 1 Tomohon. J Keperawatan. 2014;2(2).

2. Eva Ellya Sibagariang. Kesehatan Reproduksi Wanita (Edisi Revisi). Jakarta Timur: Cv. Trans Info Media; 2016.

3. Khusen D. Rahasia Kesehatan Wanita. Jakarta: Fakultas Kedokteran Universitas
Indonesia; 2017.

4. Sibagariang Ee, Pusmaika R, Rismalinda. Kesehatan Reproduksi Wanita. Jakarta: Cv. Trans Info Media; 2016.

5. Pratiwi Tm, Sabilu Y, Fachlevy Af. Hubungan Pengetahuan, Stres, Penggunaan Antiseptik Dan Penggunaan Pembalut Dengan Kejadian Fluor Albus Pada Remaja Siswi Sma Negeri 8 Kendari Tahun 2017. J Ilm Mhs Kesehat Masy. 2017;2(6).

6. Setiani Ti, Prabowo T, Paramita Dp. Kebersihan Organ Kewanitaan Dan Keputihan Patologi Pada Santriwati Di Pondok Pesantren Al Munawwir Yogyakarta. J Ners Dan Kebidanan Indones. 2015;3(1):39-42.

7. Nasional Bkkb. Survey Demografi Dan Kesehatan Indonesia (Sdki) 2012. Jakarta: Bkkbn. 2013.

8. Wulandari P, Muhartati M. Hubungan Perilaku Vulva Hygiene Dengan Keputihan Patologi Pada Siswi Kelas X Di Sma Muhammadiyah 7 Yogyakarta. 2016;

9. Sumut D. Profil Kesehatan Provinsi Sumatera Utara Tahun 2012. Medan; 2012.

10. Willis Ss. Remaja Dan Masalahnya. Bandung: Alfabeta; 2017.

11. Sarwono Sw. Psikologi Remaja. Revisi. Jakarta: Pt Raja Grafindo Persada; 2013.

12. Marpaung Ra. Analisa Faktor Perilaku Yang Mempengaruhi Terjadinya Keputihan Pada Siswi Smk Negeri 8 Medan. Anal Fakt Perilaku Yang Mempengaruhi Terjadinya Keputihan Pada Siswi Smk Negeri 8 Medan.

13. Ilmiawati $\mathrm{H}$, Kuntoro $\mathrm{K}$. Pengetahuan Personal Hygiene Remaja Putri Pada Kasus Keputihan. J Biometrika Dan Kependud. 2017;5(1):43-51.

14. Persia A, Gustia R, Bahar E. Hubungan Pemakaian Panty Liner Dengan Kejadian Fluor Albus Pada Siswi Sma Di Kota Padang Berdasarkan Wawancara Terpimpin (Kuisioner). J Kesehat Andalas. 2015;4(2).

15. Abrori A, Hernawan Ad, Ermulyadi E. Faktor Yang Berhubungan Dengan Keputihan Patologis Siswi Sman 1 Simpang Hilir Kabupaten Kayong Utara. Unnes J Public Heal. 2017;6(1):24-34.

16. Muhammad I. Pemanfaatan Spss Dalam Penelitian Bidang Kesehatan Dan Umum. Suroyo Rb, Editor. Bandung: Citapustaka Media Perintis; 2015.

17. Kumala I, Andyantoro I. Kesehatan Reproduksi Untuk Mahasiswa Kebidanan 
Dan Keperawatan. Jakarta Selatan: Salemba Medika; 2013.

18. Sari Pm. Hubungan Antara Pengetahuan Dan Sikap Remaja Dengan Kejadian Fluor Albus Remaja Putri Smkf X Kediri. J Wiyata Penelit Sains Dan Kesehat. 2017;3(1):1-4.

19. Notoatmodjo S, Anwar H, Ella Nh, Tri K. Promosi Kesehatan Dan Perilaku Kesehatan. Jakarta: Rineka Cipta. Jakarta: Pt Rineka Cipta; 2012. 21-23 P.

20. Tristanti I. Hubungan Perilaku Personal Hygiene Genital Dengan Keputihan Pada Siswi Madrasah Aliyah Muhammadiyah Kudus. J Ilmu Keperawatan Dan Kebidanan. 2016;7(1).

21. Farage Ma, Enane Na, Baldwin S, Berg Rw.
Labial And Vaginal Microbiology: Effects Of Extended Panty Liner Use. Infect Dis Obstet Gynecol. 1997;5(3):252-8.

22. Astuti Dw. Hubungan Penggunaan Panty Liner Dengan Keputihan Di Sma Muhammadiyah 3 Yogyakarta. 2017;

23. Triyani R, Ardiani S. Hubungan Pemakaian Pembersih Vagina Dengan Keputihan Pada Remaja Putri. Bidan Prada J Publ Kebidanan Akbid Ylpp Purwokerto. 2013;4(01). 